\title{
15. OXYGEN AND CARBON ISOTOPE ANALYSES OF TERTIARY AND CRETACEOUS MICROFOSSILS FROM SHATSKY RISE AND OTHER SITES IN THE NORTH PACIFIC OCEAN
}

\author{
Robert G. Douglas, Department of Geological Sciences, University of Southern California, Los Angeles, California \\ and \\ Samuel M. Savin, Department of Earth Sciences, Case Western Reserve University, Cleveland, Ohio
}

\begin{abstract}
Oxygen and carbon isotopes were determined for nannofossils and foraminifera of Tertiary and Cretaceous age recovered at sites drilled on Shatsky and Hess rises during Leg 32. Additional samples of microfossils from other DSDP sites on Shatsky Rise and on Magellan Rise were also analyzed for comparative purposes.

Progressive lithification in pelagic carbonate sediments results in the partial isotopic adjustment of microfossil calcite as dissolved $\mathrm{CaCO}_{3}$ is deposited as overgrowth cement. In this process nannofossils, particularly discoasters, are preferentially overgrown and show the largest isotopic adjustment. Nannofossils from midTertiary sediments yield $\delta \mathrm{O}^{18}$ values that differ from associated planktonic foraminifera by more than 1.0 per mil, although the original isotopic composition of the two groups was similar. Only nannofossils from depths of burial of less than about 200 meters, where little cement overgrowth has occurred, retain their original isotopic composition. Foraminifera, which tend to act as donors in the $\mathrm{CaCO}_{3}$ transfer, are less affected isotopically by diagenesis. Planktonic foraminifera retain their isotopic composition from sediments as old as Late Cretaceous at Site 305 and benthonic species from Early Cretaceous sediments at Site 306. Because of their different preservation characteristics, foraminifera are more reliable isotopic paleotemperature indicators than are nannofossils.

Microfossils from Shatsky Rise yield oxygen-isotope paleotemperatures that suggest a warming trend in the Early Cretaceous, a thermal maximum in the Albian, and a cooling trend in the Late Cretaceous. Bottom-water temperatures were warm, and the difference between surface waters and bottom waters in tropical regions was less than one-half of the present-day value. There is a small drop in temperature across the Cretaceous-Tertiary boundary which begins in the latest Campanian and ends in the Paleocene. The change in the central Pacific corresponds to approximately $2.5^{\circ} \mathrm{C}$ in surface waters and $3^{\circ} \mathrm{C}$ in bottom waters.
\end{abstract}

\section{INTRODUCTION}

Oxygen- and carbon-isotope ratios were determined for foraminifera and nannoplankton from Cenozoic and Cretaceous cores at Sites 305, 306, and 310. Analyses were made of mixed species assemblages of nannofossils, planktonic foraminifera, and benthonic foraminifera and a few individual species of planktonic foraminifera. For comparative purposes, nannofossils were also analyzed from Tertiary core samples from Sites 47 and 167.

Sites 305 and 306 are located towards the southwestern end of Shatsky Rise $\left(32^{\circ} \mathrm{N}, 157^{\circ} \mathrm{E}\right)$ in 2903 and 3399 meters of water, respectively (Figure 1). Site 305 is located near Sites 47 and 48, and Site 306 is located near Sites 49 and 50 of Leg 6. At Site 305, 640 meters of calcareous ooze, chalk, limestone, and chert were drilled, ranging in age from Quaternary to Hauterivian or Valanginian. Core recovery was poor below the Campanian and basement was not reached. Site 306 was drilled in order to penetrate the entire Mesozoic section on Shatsky Rise and to reach basement. At this site 380 meters of chert were cored and the hole bottomed in Valanginian to Berriasian sediments perhaps about 80 meters above basement. Together, the two cored sections make up a complete stratigraphic sequence from the Berriasian to the Quaternary, with minor hiatuses between early Miocene and late Oligocene and between early Eocene and Paleocene (Figure 2). Site 305 provides the most complete and continuously cored lower Paleogene section available in the Pacific Ocean and, in combination with Site 306, one of the most complete Cretaceous sections of nonlimestone carbonate drilled in the oceans. Oxygen- and carbon-isotope analyses were undertaken to examine the effects of carbonate diagenesis and lithification on isotopic paleotemperature and to extend the oxygen-isotope paleotemperature curves derived from previously analyzed Pacific sites (Douglas and Savin, 1971, 1973; Savin et al., in press).

\section{SAMPLE PREPARATION}

The method of preparation and analysis of foraminifera was identical to that described by Douglas and Savin (1971, 1973). Mixed species of nannofossils 


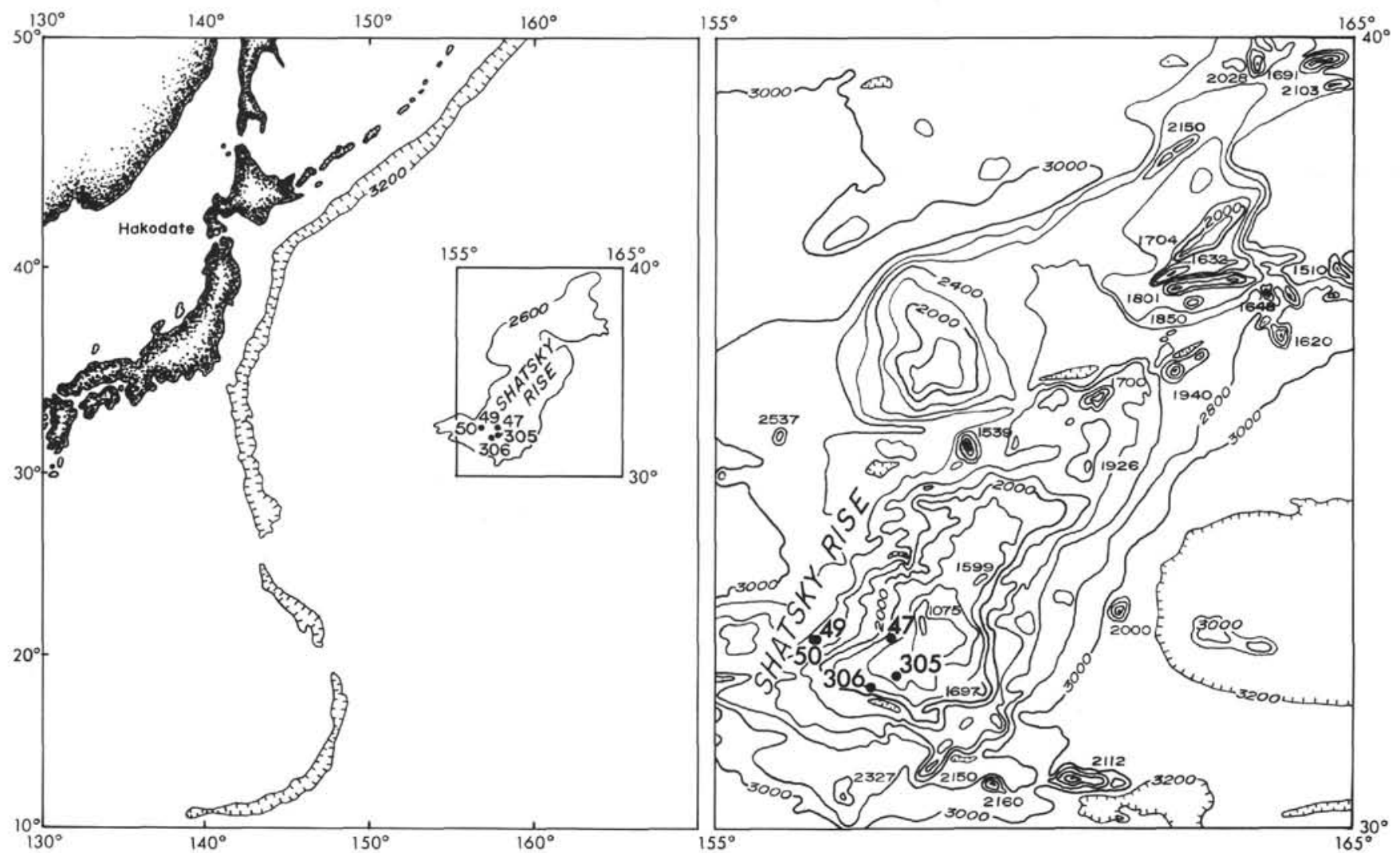

Figure 1. Location of principal drill sites from which microfossils were isotopically analyzed. Sites 47 and 50 were drilled during Leg 6 (see Douglas and Savin, 1971) and Sites 305 and 306 during Leg 32.

were prepared in the following manner. Samples were wet sieved and the less than 38 micrometer fraction was retained and passed through a settling tube or centrifuged in order to concentrate the greater than 10 micrometer fraction. The concentrate was repeatedly centrifuged until the residue was greater than about $90 \%$ nannofossils. After concentration, the residues were prepared and analyzed in the same manner as foraminifera.

The microfossils were analyzed for isotopes using standard techniques (Epstein et al., 1951), after crushing, ultrasonic cleaning, and treating with $10 \%$ sodium hypochlorite (Clorox), and washing. The results are reported in notation as per mil deviations from the PDB (standard by means of the secondary standard NBS-20 (Solenhofen limestone) which is assumed to have a $\delta \mathrm{O}^{18}$ value of -4.14 per mil and a $\delta \mathrm{C}^{13}$ value of 1.06 per mil relative to PDB (Craig, 1957). Precision of the isotopic analyses is generally better than 0.1 per mil. Isotopic temperatures were calculated using the equation of Craig (1965) and the assumption that the isotopic composition of seawater in which the plankton tests grew was 0.00 per mil relative to Standard Mean Ocean Water (SMOW) and that the shells of benthonic foraminifera grew in water with an isotopic ratio of 0.60 per mil relative to SMOW. The calculated temperatures may be systematically a few degrees higher or lower than actual growth temperatures because of uncertainties in the isotopic composition of seawater in the Tertiary and Cretaceous and because the shells of some foraminifera may not have grown in isotopic equilibrium. A general discussion of the paleoecological influences which affect isotopic paleotemperature is given in Savin et al., in press.

\section{RESULTS}

The sample interval, age, and isotopic results obtained for the analyzed samples from Sites 305,306 , and 310 and the comparative samples from Sites 47 and 167 are given in Table 1. The downhole distribution of $\delta \mathrm{O}^{18}$ and $\delta \mathrm{C}^{13}$ values at Sites 305 and 306 are shown in Figures 3 and 4.

Figure 5 shows the oxygen ratios of nannofossils and planktonic foraminifera from the Quaternary at Site 305 together with data from Sites 47 and 167. Planktonic foraminifera were previously analyzed at the two latter sites, and the basic data for these determinations are contained in Douglas and Savin $(1971,1973)$. The nannofossils from the same samples at these two sites were analyzed as well as those from the same stratigraphic interval at Site 305. At the time of this writing, the planktonic foraminifera from the Tertiary of Site 305 have not been completed and are not included in Table 1. These analyses were originally intended to determine the amount of isotopic variation to be expected between samples of mixed species assemblages of the same age from different locations and to obtain independent estimates of sea-surface paleotemperatures from two unrelated fossil groups. However, it soon became apparent that the isotopic composition of nannofossils, especially 


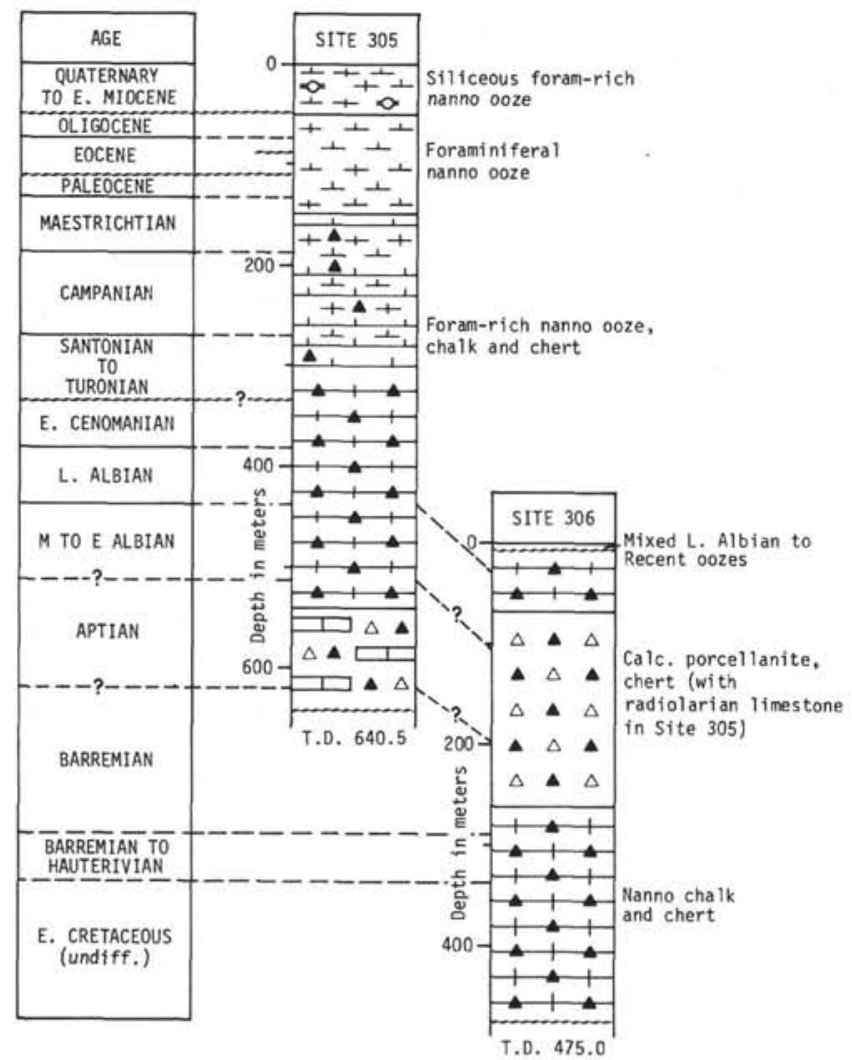

Figure 2. Generalized stratigraphic column of the section drilled at Sites 305 and 306. The Cretaceous lithology at Site 306 is interpreted almost entirely from core-catcher samples.

discoasters, is affected by the overgrowth of calcite during lithification of the sediments. Consequently, it seems more indicative of the diagenetic condition of the sediments than of the original isotopic composition of the seawater in which the tests were grown. As shown in Figure 5, samples of the same age from Sites 47 and 305 , which have a similar diagenetic history, yield similar $\delta \mathrm{O}^{18}$ results. However, Site 167 , which has a much thicker Tertiary section $(130 \mathrm{~m}$ versus $670 \mathrm{~m})$ and has undergone a greater degree of lithification in the midTertiary portion of the section, yielded different isotopic results for samples of the same age. The isotopic analyses, when combined with the downhole trends in strontium and magnesium and petrographic examination of the sediments, provide a fairly lucid picture of the diagenetic changes which occur in pelagic deep-sea carbonate sediments (see Matter et al., this volume). The selective influence of diagenesis on the isotopic composition of nannofossils, planktonic foraminifera, and benthonic foraminifera and therefore the paleotemperature interpretation is very apparent. In the following paragraphs we examine briefly this problem and the paleotemperature implications of the Cretaceous isotopic results.

\section{Diagenetic Effects on the Isotopic Composition of Nannofossils and Foraminifera}

The skeletal elements of nannoplankton and the shells of planktonic foraminifera are grown in the surface layers of the ocean. The oxygen-isotope composition of these microfossils provide estimates of sea-surface temperatures. Benthonic foraminifera, which secrete their tests on the bottom, provide estimates of the oxygenisotope composition of bottom-water temperatures. The accuracy with which the oxygen-isotope ratios reflect original temperatures during growth and provide a basis for reconstructing climatic curves is dependent upon a number of factors. One of the most important factors, a major assumption in the oxygen-isotope paleotemperature method, is that the isotopic composition of the biogenic carbonate remains stable and diagenetically unaltered after burial.

In all of the pelagic carbonate sections drilled by Glomar Challenger, there is a change in lithology from ooze to chalk to limestone with increasing depth of burial. These lithologic changes are the result of progressive dissolution of the more soluble planktonic foraminifera, the delicate coccoliths, and the micritic carbonate grains formed by the breakdown of the tests and the reprecipitation of the dissolved $\mathrm{CaCO}_{3}$ as overgrowth and cement on the more robust nannoplankton and foraminifera (Matter, 1974; Schlanger and Douglas, 1974). This transfer of $\mathrm{CaCO}_{3}$ by the processes of dissolution and reprecipitation has been documented in cores from Sites 305 and 306 by Matter et al. (this volume), who examined trends with depth of trace element concentrations, microfossil preservation, and lithology. The processes tend to selectively alter the original isotopic composition of the microfossils in two ways. First, dissolution selectively removes those species of planktonic foraminifera which lived at shallowest depth and had the warmest growth temperatures (Douglas and Savin, 1973; Savin and Douglas, 1973). Therefore, isotopic analyses of mixed species assemblages of planktonic foraminifera yield progressively cooler temperatures with increasing dissolution. The extent to which the original isotopic composition of the nannoplankton assemblages is affected by dissolution is unknown, but we would expect an effect similar to that of the foraminifera.

Second, the diagenetically precipitated $\mathrm{CaCO}_{3}$ has an $\mathrm{O}^{18} / \mathrm{O}^{16}$ ratio reflecting its formation at the cold temperatures at or near the sediment-water interface. The $\mathrm{CaCO}_{3}$ that is analyzed is a mixture of carbonate biogenically precipitated in near-surface waters and carbonate formed diagenetically at near-bottom conditions. Thus, its $\mathrm{O}^{18} / \mathrm{O}^{16}$ ratio will be greater than that of the unaltered planktonic $\mathrm{CaCO}_{3}$, and the oxygen-isotope paleotemperature will be correspondingly colder. The diagenetically precipitated $\mathrm{CaCO}_{3}$ is preferentially deposited on nannofossils during the early stages of diagenesis.

The friable ooze-chalk becomes a more compact chalk as lithification proceeds until, finally, a limestone forms. As cementation proceeds, the more stable foraminiferal species become overgrown. Observations on the downhole preservation of foraminifera from Sites 305 and 306 are in agreement with these findings (see Matter et al., this volume). Thus, in the lithification process, the isotopic composition of nannofossils may be partially altered by the addition of new calcite with a different oxygen-isotope ratio while associated foraminifera may be unaffected. 
TABLE 1

Sample Data, Paleontological Age, Preservation of Planktonic Foraminifera, Type of Sample, and Isotope Results of Samples Analyzed

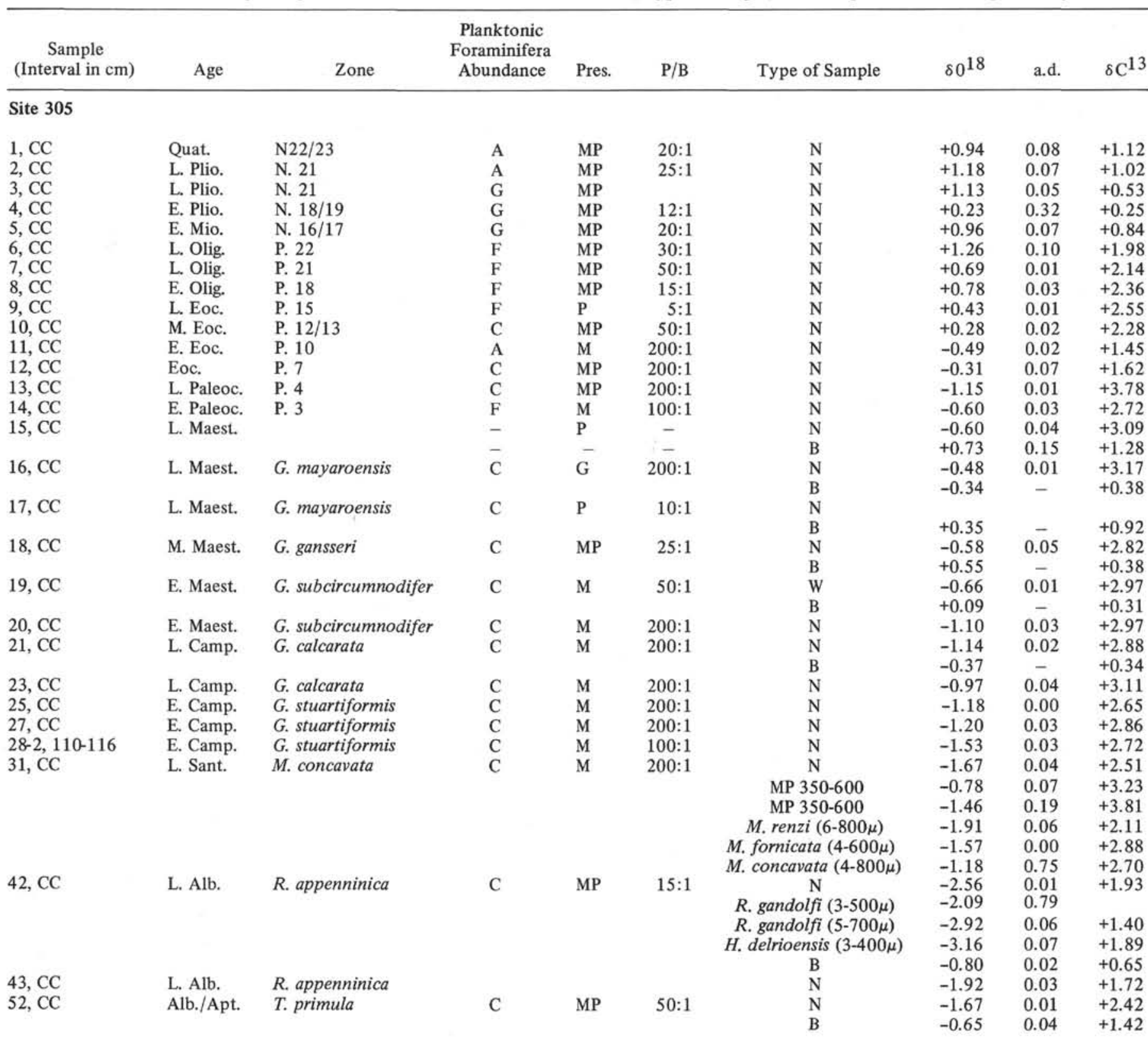

Site 306

$\begin{array}{lll}\text { 4-1, 112-115 } & \text { Alb. } & \text { T. primula } \\ \text { 20-1, 115-119 } & \text { Barr.-Haut. } & \text { D. zedlarae } \\ \text { 21-1, 74-78 } & \text { Barr.-Haut. } & \text { D. zedlarae } \\ \text { 24, CC } & \text { Valang. } & \text { D. hauteriviana } \\ & & \\ \text { 36, CC } & \text { Val.-Berr } & - \\ \text { 39, CC } & & \end{array}$

$\begin{array}{ll}\mathrm{C} & \mathrm{P} \\ \mathrm{F} & \mathrm{MP} \\ \mathrm{F} & \text { MP } \\ & \text { MP } \\ & \\ & \text { MP }\end{array}$

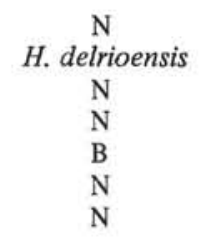

$\begin{array}{lll}-2.39 & 0.05 & +2.73 \\ -2.85 & 0.02 & +2.36 \\ -2.14 & 0.02 & +2.03 \\ -2.10 & 0.02 & +1.70 \\ -0.64 & 0.04 & -0.77 \\ -3.14 & 0.07 & +1.25 \\ -1.49 & 0.07 & +1.91\end{array}$

\section{Hole 49-1}

$2-2$

Barr.-Haut.

$\mathrm{N}$

$-1.07$

0.01

$+2.68$

Hole $\mathbf{5 0 . 0}$

\section{$2-3,0-5$ \\ 2-6, $0-5$}

2, CC
Barr.-Haut.

Barr.-Haut.

Barr.-Haut.

$\begin{array}{lll}\text { F } & \text { M } & - \\ \text { F } & \text { M } & - \\ \text { F } & \text { M } & -\end{array}$

\begin{tabular}{lll}
-1.07 & 0.02 & +1.70 \\
-1.09 & 0.01 & +1.93 \\
-0.50 & 0.03 & -0.34 \\
\hline
\end{tabular}




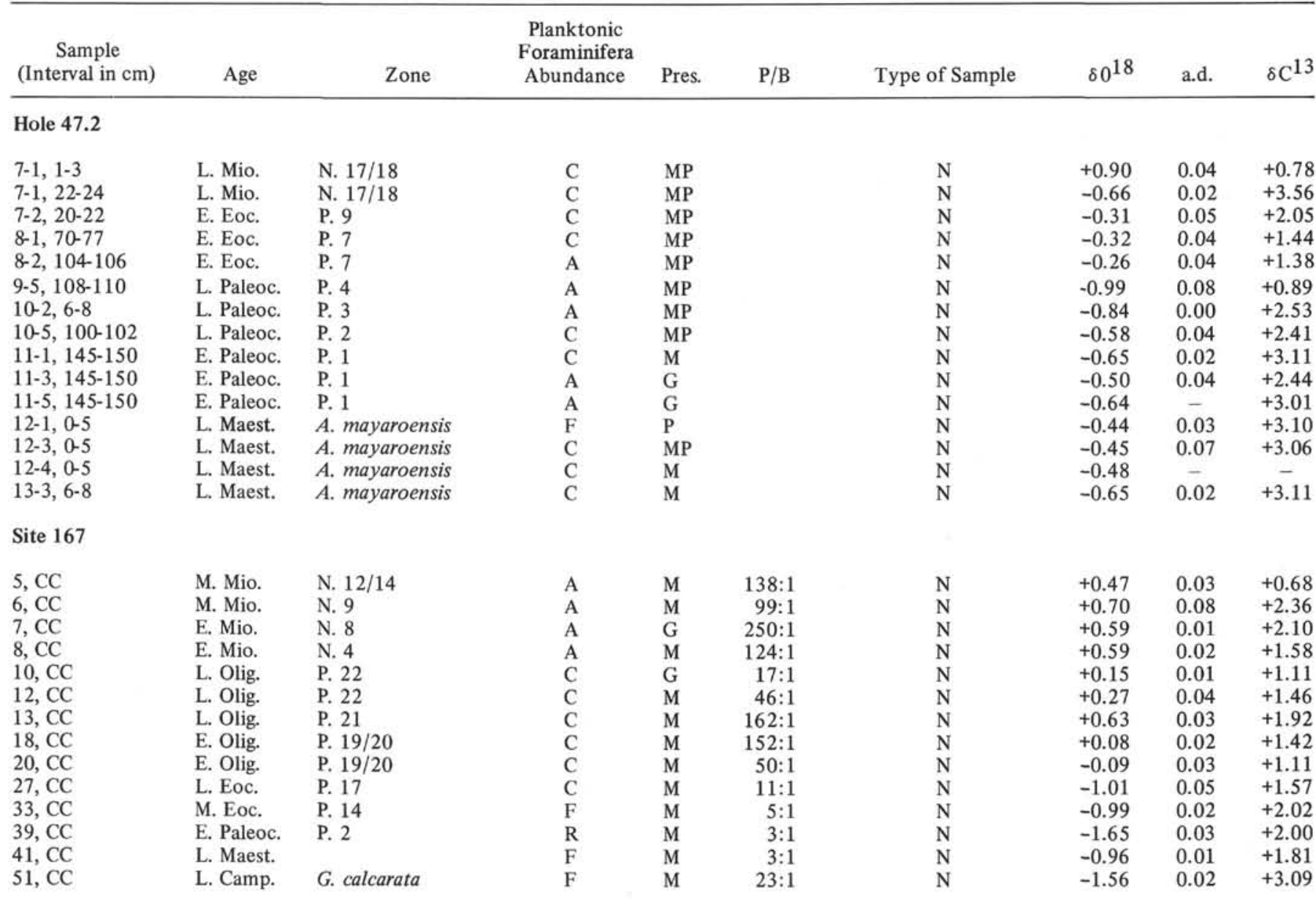

Site 310

\begin{tabular}{|c|c|c|c|c|c|}
\hline $1 \mathrm{~A}, \mathrm{CC}$ & Maest. & $\mathrm{N}$ & -0.76 & 0.09 & +2.90 \\
\hline
\end{tabular}

Note: $\mathrm{N}=$ mixed species of nannofossils; $\mathrm{B}=$ mixed species of benthonic foraminifera; $\mathrm{MP}=$ mixed species of planktonic foraminifera; $\mathrm{P} / \mathrm{B}=\mathrm{ratio}$ of planktonic to benthonic foraminifera, based on a random count of 500 individuals.

Oxygen-isotope ratios of mixed species assemblages of nannofossils from Recent sediments (Douglas and Savin, unpublished data), yield lighter $\delta \mathrm{O}^{18}$ values than planktonic foraminifera from the same samples. Nannoplankton apparently secrete most of their skeletal carbonate in the photic zone, nearer to the sea surface (i.e., in slightly warmer water) than, on the average, do species of planktonic foraminifera. Plio-Pleistocene samples from the soft oozes at Sites 47, 305, and 167 show this expected relationship. These samples come from shallow burial depths, generally less than 50 meters below the sea floor, and, while a considerable amount of dissolution has occurred, there is little or no evidence of calcitic overgrowth. Based on the planktonic to benthonic foraminifera ratios obtained from core-catcher samples in this interval, about $90 \%$ of the planktonic foraminifera have been destroyed by dissolution at Site 305 , and about $80 \%$ at Site 167 (Douglas, 1973). However, the oxygen-isotope ratios of the biogenic carbonate appear to be unaffected. Individual species of planktonic foraminifera yield isotopic temperatures whose ranking agrees with the known rankings of their depth habitats. Thus, except for the selective removal of certain species by dissolution, diagenesis has little or no effect on the isotopic composition of the biogenic constituents of soft oozes in the top few tens of meters of sediment.

Below about 50 meters the sediment at Site 305 changes from soft ooze to stiff ooze composed of nearly pure carbonate (Matter et al., this volume). A similar change in lithology at about the same depth occurs at Site 167 (Schlanger et al., 1973). In this interval and farther downhole, as the ooze becomes chalk, a large amount of dissolved calcite is reprecipitated as thick overgrowths on discoasters and coccoliths. As the chalks become more lithified, overgrowths and chamber infillings accrete on the more robust coccoliths and planktonic and benthonic foraminifera (Douglas, 1973). These textural changes are accompanied by large decreases in strontium and magnesium of the bulk sediment (Matter et al., this volume). Nannofossil assemblages from these sediments yield $\delta \mathrm{O}^{18}$ values which are 


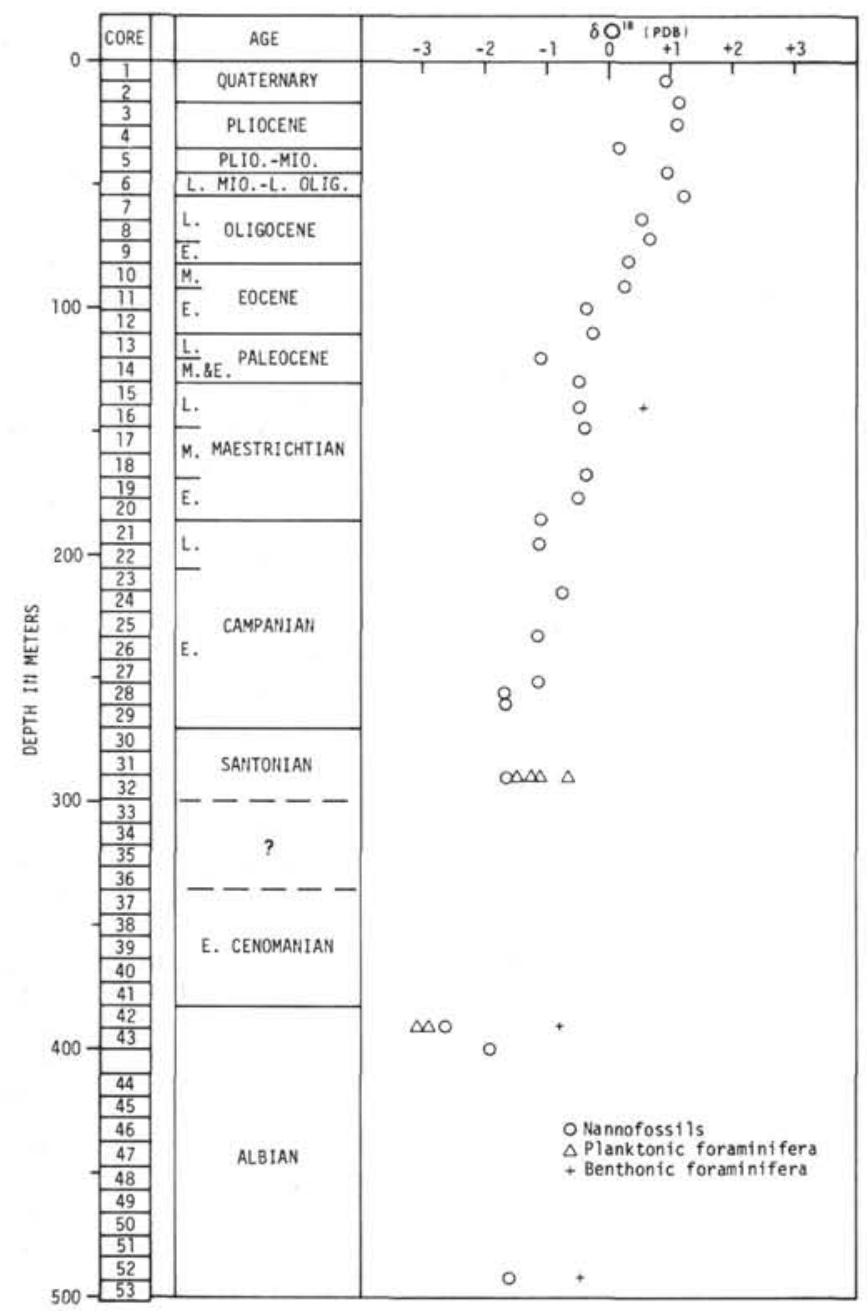

Figure 3. Downhole variation in $\delta 018$ at Site 305. The spare analyses below Core 32 is due to poor core recovery and lack of suitable material for determination.

normally heavier than those of planktonic foraminifera. While the two microfossil groups give a similar trend in the isotopic values downhole, they differ by about 1.0 per mil in the Miocene, 0.5 per mil in the Oligocene and Eocene, and about 0.25 per mil in the Paleocene and Late Cretaceous chalks at Sites 47 and 305 (Figure 5).

The complex relationship between the $\delta \mathrm{O}^{18}$ values of nannofossils and foraminifera described above and the variation of this relationship with age and depth of burial are the result of a combination of factors. The consistently colder isotopic temperatures of benthonic foraminifera than of planktonic may be taken as evidence that biogenic carbonate which has not dissolved does not re-equilibrate with pore water. Even stronger evidence for this is the consistent preservation of isotopic temperature rankings of planktonic foraminiferal species from a sample, which are concordant with rankings of depth of growth habitat predicted from test morphology. Re-equilibration of biogenic calcite would destroy these consistent rankings. Alteration of isotopic compositions in pelagic carbonates during the early stages of diagenesis involves, primarily, the formation of

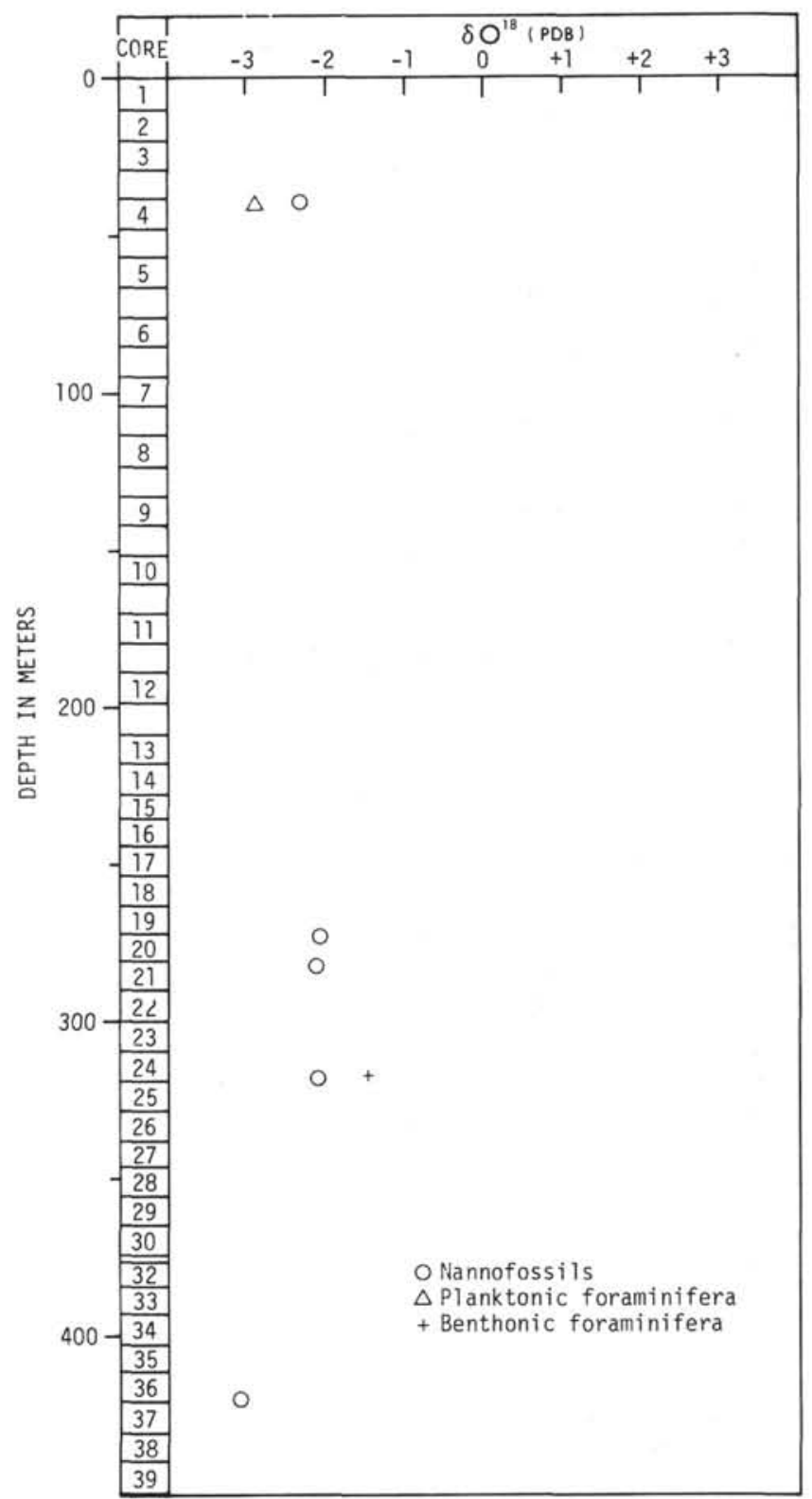

Figure 4. Downhole variation in $\delta 018$ at Site 306.

overgrowth cement on nannofossils. Foraminifera act as donors in the $\mathrm{CaCO}_{3}$ transfer and they do not become overgrown until the sediment becomes a well-lithified chalk (Schlanger et al., 1973; Schlanger and Douglas, 1974). However, even in the foraminiferal specimen from compact chalk, the isotopic composition is probably little affected by overgrowth cement because much of it is removed during sample disaggregation and ultrasonic cleaning of the foraminiferal residues. Thus, there is no evidence to suggest that the isotopic composition of the Tertiary and Late Cretaceous foraminifera analyzed from Sites 167 and 305 has been significantly altered.

The oxygen-isotope ratios of the nannofossils at all but the shallowest layers of the sediments must represent mixtures of calcite precipitated in surface waters and calcite formed diagenetically as overgrowths. Visual es- 


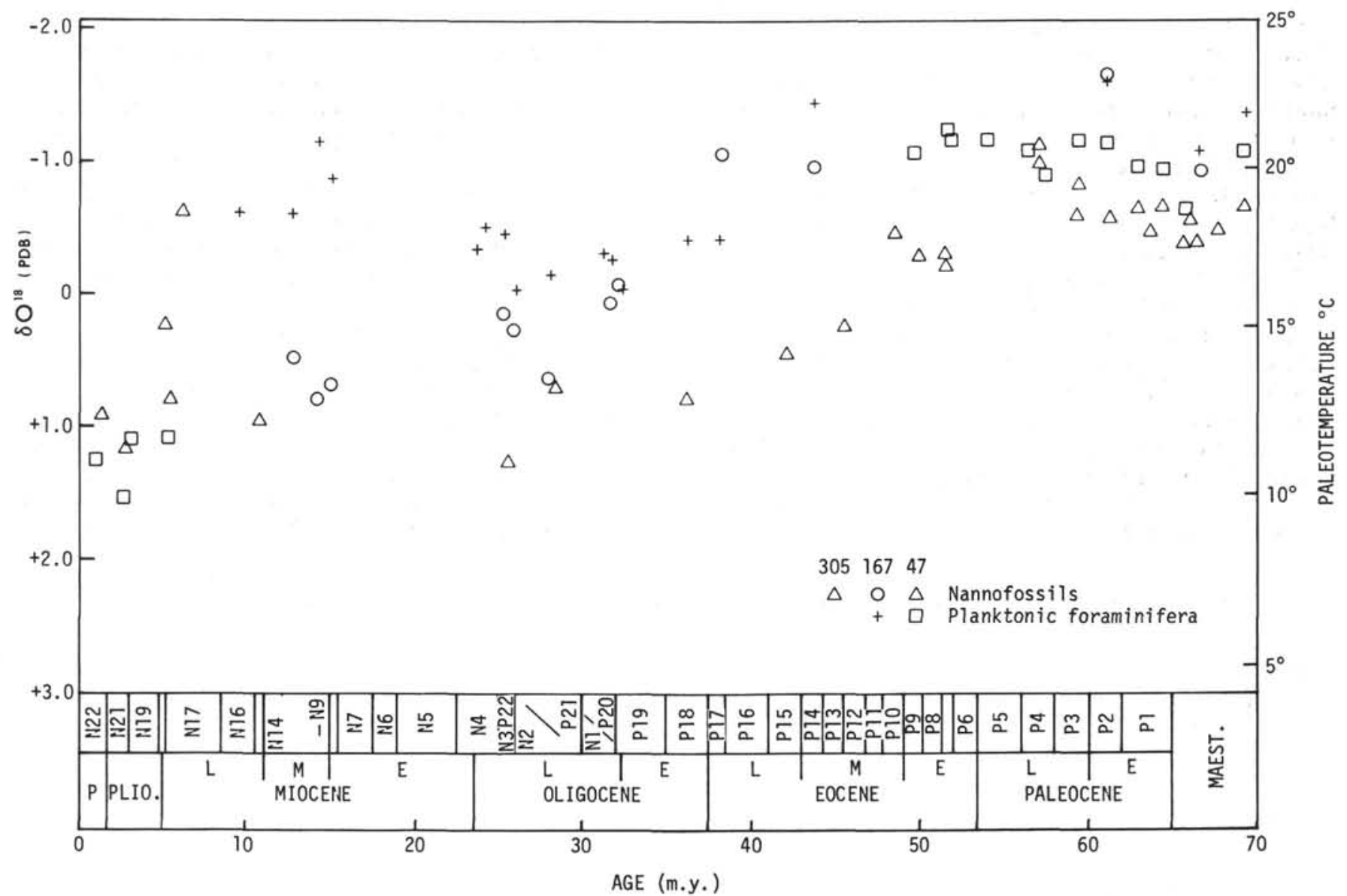

Figure 5. Compilation of Cenozoic results from Sites 47, 167, and 305, based on nannofossils and planktonic foraminifera. Note that the two groups yield similar $\delta 018$ values in Pleistocene-Pliocene and Paleocene sediments but differ markedly in The Miocene and Oligocene.

timates of the relative amount of accreted calcite on an individual nannofossil vary from $50 \%$ to about $200 \%$ of the mass of the initial microfossil, based on the photomicrographs of overgrown coccoliths and discoasters from Site 305 (Matter et al., this volume) and other DSDP sites (e.g., Bukry, 1973; Roth, 1973). If we assume that the original oxygen-isotopic composition of the nannofossil was the same as that of the planktonic foraminifera and the amount of calcite cement added is $100 \%$ of the original calcite then our simple calculations show that the isotopic composition of the overgrowth is similar in most cases to that of benthonic foraminifera in the same sample. For this reason, we believe that the overgrowth of the nannofossils probably occurred no deeper than a few hundred meters below the sea floor, within the shallow-burial realm of Schlanger and Douglas (1974) where the temperature was close to bottomwater temperature. The trend of cooling isotopic temperatures of nannofossils from the Paleocene to the late Oligocene reflects, in part, cooling bottom-water temperature during that time. Miocene nannofossils became overgrown under conditions of cold bottom waters (probably sometime in the late Miocene or Pliocene), and yield isotopic temperatures which are significantly colder than planktonic foraminifera from the same sample. On the other hand, Paleocene nan- nofossils re-equilibrated under conditions of warm bottom waters and shallow surface-to-bottom temperature gradients (Savin et al., in press) and the nannofossils of that age give isotopic temperatures only slightly colder than the foraminifera. The large difference ( 0.8 per mil) between the $\delta \mathrm{O}^{18}$ values of nannofossils and planktonic foraminifera from the early Eocene at Site 47 suggests that the overgrowth of the nannofossils did not occur in the early or middle Eocene when bottom waters were warm but sometime after the rapid cooling of bottom waters, which occurred at the end of the Eocene (Douglas and Savin, 1973; Savin et al., in press).

\section{Cretaceous Paleotemperatures}

In an attempt to extend the marine paleotemperature record back into the Cretaceous, the oxygen-isotope ratios of microfossils from Sites $49,50,305,306$, and 310 were analyzed. Paleolatitudes of these sites were in the tropics for most of the Cretaceous (Lancelot and Larson, this volume). Isotopic analyses have previously been made on Cretaceous deep-sea carbonates collected on Leg 15 (Anderson and Schneidermann, 1973) and Leg 17 (Coplen and Schlanger, 1974; Douglas and Savin, 1973). However, the analyses were of bulk sediments, and the results were not primarily intended for paleotemperatures. 
The original, and most comprehensive, isotopic paleotemperature study of the Cretaceous was by Lowenstam and Epstein (1954) who examined belemnites and other invertebrates from the chalks of northwest Europe. Recently, Spaeth et al. (1971) have analyzed additional belemnites from the same region and conclude that few specimens retained their original isotope values. Nevertheless, their isotopic results closely match the trends obtained by Lowenstam and Epstein.

The results of the determinations are presented in Table 1 and graphically in Figures 6 and 7. It can be seen on Figure 6 that our samples are concentrated in the Late Cretaceous (late Santonian to Maestrichtian), and that the rest of the period is covered by about 12 samples. Despite the paucity of samples, there is at least one determination per stage, except for the Coniacian. Combined with data from Leg 17 (Douglas and Savin, 1973), the data are adequate to indicate the broad isotopic trends for the period.
The preservation of the Late Cretaceous foraminifera in Site 305 samples (down to Core 31) is good except for some signs of dissolution, and we detected no evidence of overgrowth cement. Thus, we believe these microfossils have unaltered isotope values. Foraminifera from Sites 49,50 , and 306 showed signs of both dissolution and minor amounts of calcite overgrowths. An attempt was made to analyze specimens which exhibited little or no overgrowth cement, so that any isotopic contamination by diagenetic calcite cement was minimized. Because it was not possible to completely eliminate overgrowths, $\delta \mathrm{O}^{18}$ values of these samples may reflect minor diagenetic alteration.

The nannofossils from the Cretaceous sample all exhibit secondary additions of calcite, and the amount of overgrowth is large in samples from Site 306 (see Matter et al., this volume; Bukry, this volume). As discussed above, in spite of the formation of overgrowths, the gross features of temperature fluctuation with time tend

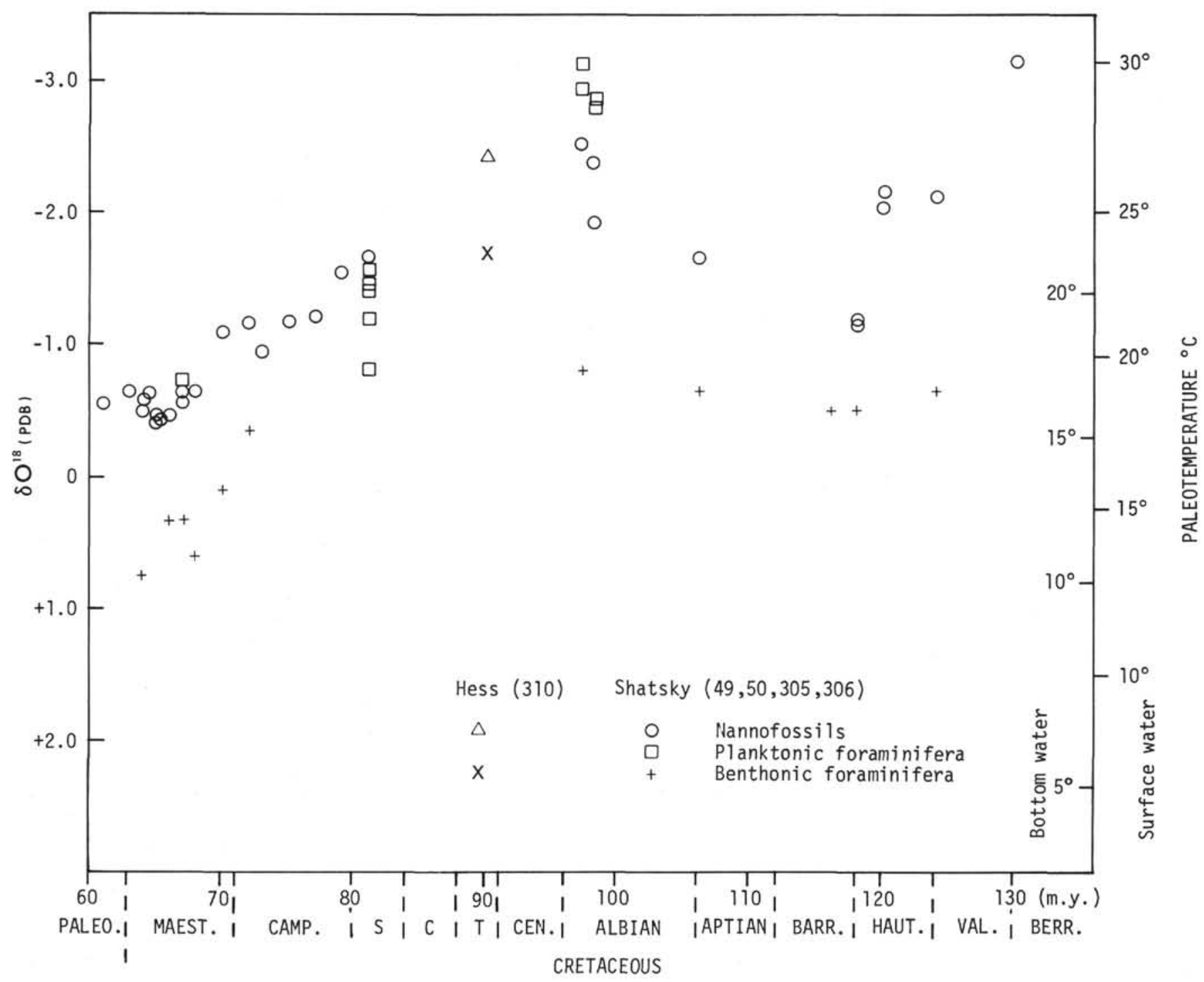

Figure 6. Compilation of Cretaceous results from Sites 49, 50, 305, 306, and 310, based on nannofossils, planktonic foraminifera and benthonic foraminifera. Note that a different isotopic composition of seawater is assumed for surface-water temperature and bottom water temperature 


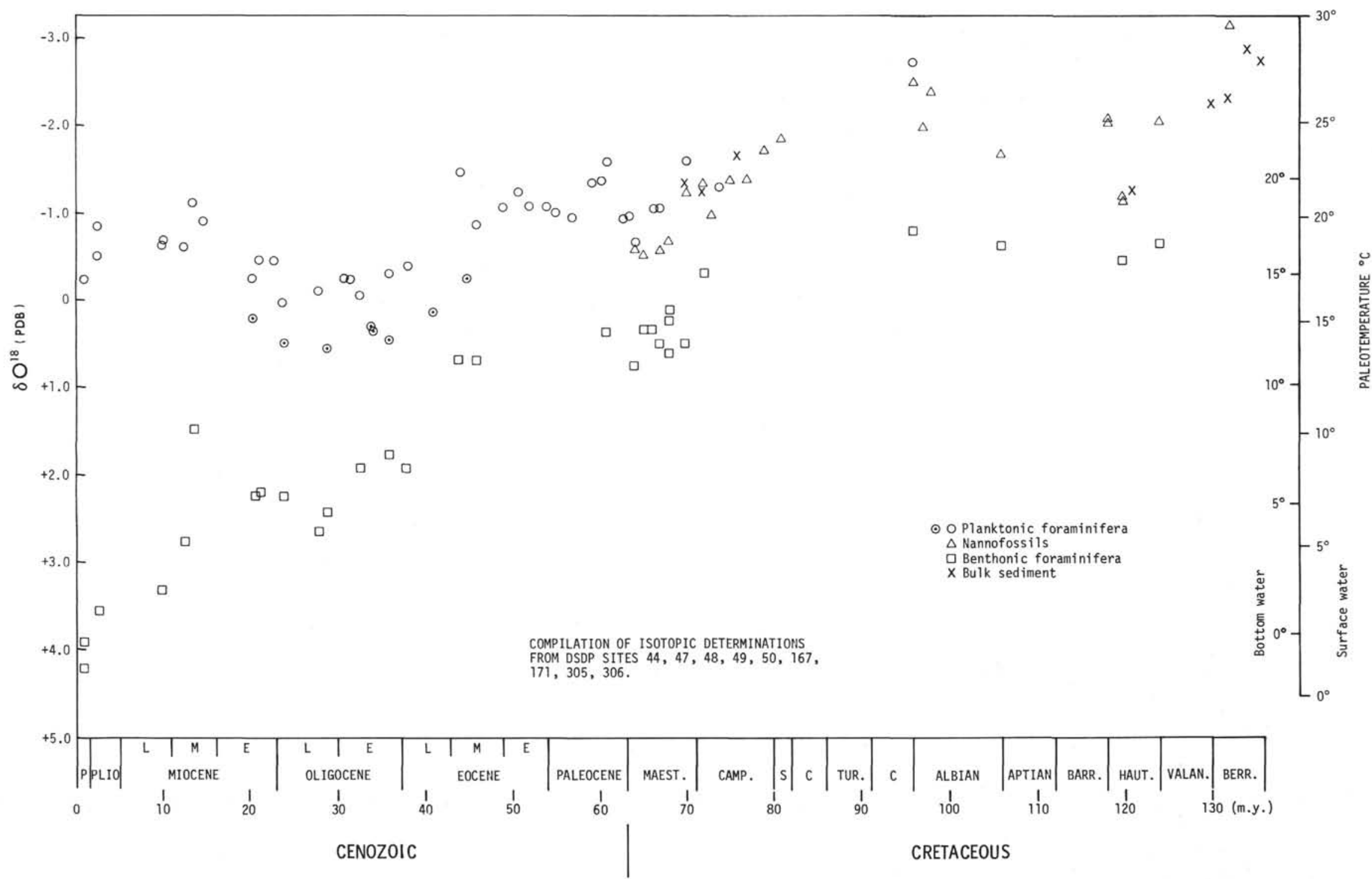

Figure 7. Paleotemperature determination based on belemnite and brachipods from Northwestern Europe. (a) Data from Lowenstam and Epstein (1954) (b) Data from Spaeth et al 1971. 
to be preserved in such samples although the actual growth temperatures are not.

The Cretaceous isotopic ratios from the Shatsky Rise contain three separate paleotemperature signals: (1) Foraminifera, especially the benthonic species, from Sites 47,50 , and 365 appear to be isotopically unaltered. Therefore they give reasonable estimates of surface and bottom-water isotopic paleotemperatures; (2) Foraminifera from Sites 306 and 310 have been contaminated by small amounts of diagenetically formed cement overgrowth. They can be used to show the relative temperature trends although they yield temperatures colder than those occurring during growth; (3) Nannofossils from Sites 49, 50, 305, 306, and 310 have been contaminated by diagenetic overgrowths and are indicative of relative temperature trends but not absolute paleotemperatures.

Bearing these constraints in mind, the isotopic record seen in Figure 6 can be interpreted as reflecting a simple climatic history with warming temperatures in the Early Cretaceous which reached a maximum in the Albian. Cooling occurred during the Late Cretaceous and a minimum was reached at the end of the Maestrichtian. Bottom-water temperatures in the Early Cretaceous differ from surface temperatures by as much as about $6^{\circ} \mathrm{C}$. In the latest Cretaceous the difference increases to about $8^{\circ} \mathrm{C}$. Based on these estimates, the tropical vertical thermal gradient in the Cretaceous was less than one-third the present-day value.

A comparison of isotope data from the Pacific with the paleotemperature data derived in northwest Europe reveals several similarities. Lowenstam and Epstein (1954) and Spaeth et al. (1971) found the warmest Cretaceous temperatures in the Albian and cooling temperatures in the Late Cretaceous. The Albian maximum was preceded by a warming trend in Europe and the Pacific that began in the Barremian or Hauterivian (Coplen and Schlanger, 1973; Spaeth et al., 1971).

Our data are widely spaced in the early Late Cretaceous, and we lack details of the temperature change between the Albian and latest Santonian. However, as can be seen in Figure 6, the trend indicated by these data is one of decreasing temperatures during the Late Cretaceous. Any reversal in this trend would have to be a short-term event. Lowenstam and Epstein (1954) found a temperature minimum in the Cenomanian followed by a second thermal maximum in the Santonian. Coplen and Schlanger (1973) also obtained very warm paleotemperatures for Coniacian-Santonian sediments in the Central Pacific. They believe the Coniacian-Santonian warming represents a worldwide climatic event. We were unable to test this idea on Shatsky or Hess rises because of poor sediment recovery.

The similarities between the isotope data from the Pacific, Atlantic, and Europe strongly suggest that the trends reflect worldwide climatic variations. It is difficult to ascribe the isotope trends to diagenetic changes because the chalks of Europe (Scholle, 1974; Hakaansson et al; 1974) have a different diagenetic-lithification history than the pelagic sediments of Magellan Rise (Schlanger et al; 1973).

The temperature history surrounding the CretaceousTertiary boundary has long been of great interest. The mass extinctions associated with this boundary have commonly been explained in terms of a major cooling or temperature change. Saito and Van Donk (1974) examined the isotopic composition of foraminifera from Campanian to Danian sediments in the South Atlantic and determined that isotopic paleotemperatures decreased about $3.5^{\circ} \mathrm{C}$ for surface waters and about $5^{\circ} \mathrm{C}$ for bottom waters.

Planktonic and benthonic foraminifera from the Shatsky Rise, which was located near the equator in latest Cretaceous-early Tertiary time (Lancelot and Larson, this volume), yield $\delta \mathrm{O}^{18}$ values that increase from the Campanian to Maestrichtian and decrease from the late Maestrichtian to early Paleocene. This change corresponds to approximately a $2.5^{\circ} \mathrm{C}$ drop for surface waters and a $4^{\circ} \mathrm{C}$ drop for bottom waters. Most of the temperature change appears to have occurred in the Campanian-early Maestrichtian and the early Paleocene, the middle to late Maestrichtian being a time of relative stability. Whereas the isotopic trends for the Pacific are the same as for the Atlantic, the magnitude of the temperature decline at the end of the Cretaceous and the recovery in the early Tertiary appears to be lower in the Pacific. This seems reasonable considering the more tropical location of Shatsky Rise at the time. In any respect, the temperature history of the Central Pacific does not suggest a climatic change of major magnitude in either surface or bottom-water conditions accompanying the onset of the Cenozoic.

\section{ACKNOWLEDGMENTS}

The authors wish to acknowledge the assistance of Ivy Yeh, Diane Eskenasy, and Fay Woodruff in preparing and analyzing samples for oxygen and carbon isotopes. This investigation was supported by NSF Grants GA 16827 and GA 31622.

\section{REFERENCES}

Anderson, T.F. and Schneidermann, N., 1973. Stable isotope relationships in pelagic limestones from the central Caribbean. In Edgar, N.T., Saunders, J.B., et al., Initial Reports of the Deep Sea Drilling Project, Volume 15: Washington (U.S. Government Printing Office), p. 795.

Bukry, D., 1973. Coccolith stratigraphy, eastern equatorial Pacific, Leg 16. In van Andel, Tj. H., Heath, G.R., et al., Initial Reports of the Deep Sea Drilling Project, Volume 16: Washington (U.S. Government Printing Office), p. 653.

Coplen, T.B. and Schlanger, S.O., 1974. Oxygen and carbon isotope studies of carbonate sediments from Site 167, Magellan Rise, Leg 17. In Winterer, E.L., Ewing, J.I., et al., Initial Reports of the Deep Sea Drilling Project, Volume 17: Washington (U.S. Government Printing Office), p. 505.

Craig, H., 1957. Isotopic standards for carbon and oxygen and correction factors for mass-spectrometric analysis of carbon dioxide: Geochim. Cosmochim. Acta, v. 11, p. 133. 1965. The measurement of oxygen isotopic paleotemperatures: Spoleta Conf. Stable Isotopes Oceanogr. Stud. Paleotemp. Proc., v. 3, p. 1.

Douglas, R.G., 1973. Planktonic foraminiferal biostratigraphy. In Winterer, E.L., Ewing, J.I., et al. Initial Reports of the Deep Sea Drilling Project, Volume 17: p. 673.

Douglas, R.G. and Savin, S., 1971. Isotopic analyses of planktonic foraminifera from the Cenozoic of the Northwest Pacific, Leg 6. In Fischer, A.G., Heezan, B.C., et al., Initial 


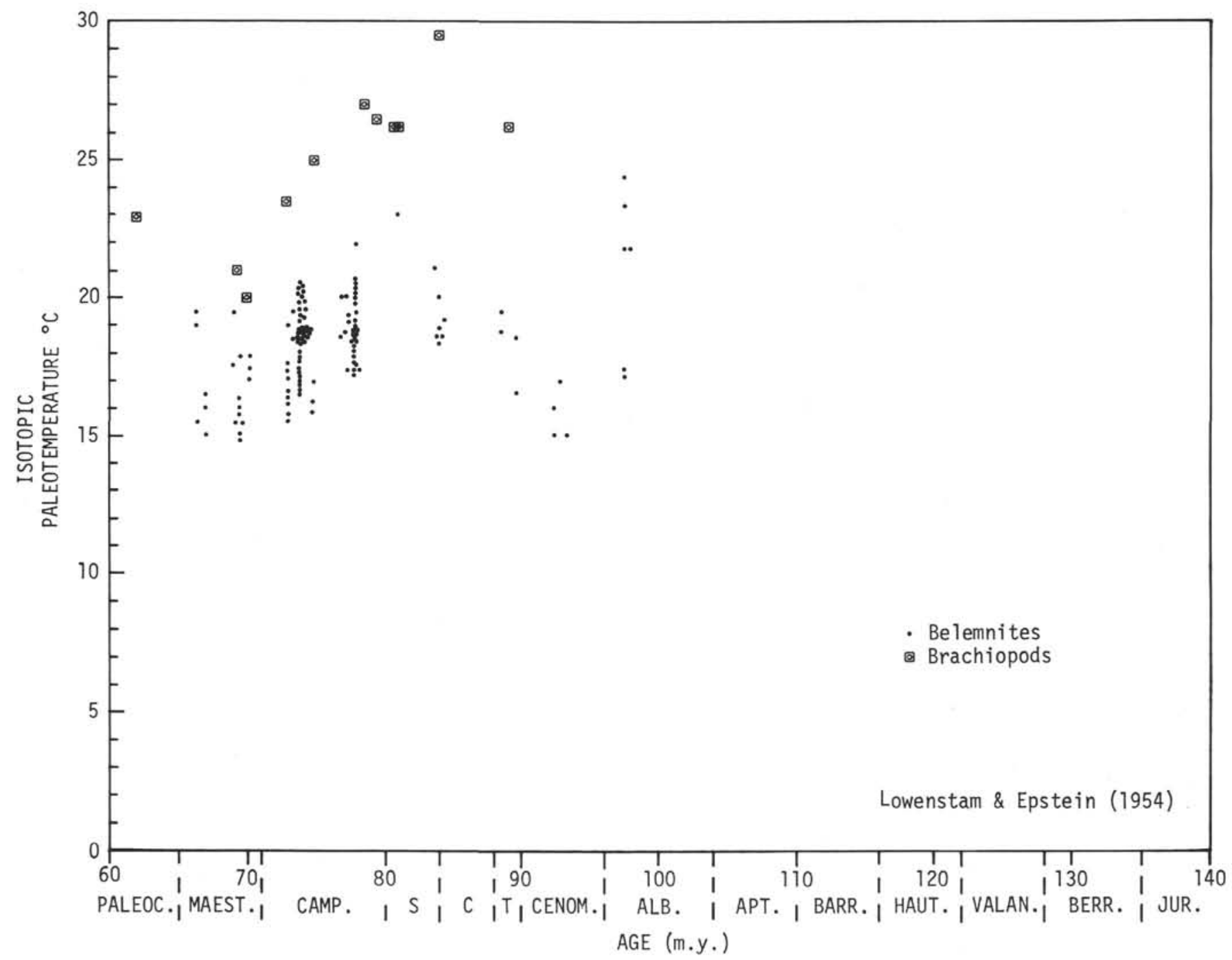

Figure 8. Oxygen-isotope paleotemperature curve for Cenozoic and Mesozoic based on DSDP sites in the central and northwest Pacific Ocean. Data from Douglas and Savin $(1971,1973$, this volume and unpublished)

Reports of the Deep Sea Drilling Project, Volume 6: Washington (U.S. Government Printing Office), p. 1123. 1973. Oxygen and Carbon isotope analysis of Cretaceous and Tertiary foraminifera from the central North Pacific. In Winterer, E.L., Ewing, J.I., et al., Initial Reports of the Deep Sea Drilling Project, Volume 17: Washington (U.S. Government Printing Office), p. 591.

Epstein, S., Buchsbaum, R. Lowenstam, H., and Urey, H., 1951. Carbonate-water isotopic temperature scale: Geol. Soc. Am. Bull., v. 62, p. 417.

Hakaansson, E., Bromley, R., and Perch-Nielsen, K., 1974. Maestrichtian chalk of Northwest Europe-a pelagic shelf sediment. In Hsü, K.J. and Jenkyns, H.C. (Eds.), Pelagic sediments: on land and under the sea; Internat. Assoc. Sediment. Petrol., Spec. Pub. 1, p. 211.

Lowenstam, H.A. and Epstein, S. 1954. Paleotemperatures of the post-Albian Cretaceous as determined by the oxygen isotope method: J. Geol. v. 62, p. 207.

Matter, A., 1974. Burial diagenesis of pelitic and carbonate deep sea sediments from the Arabian Sea: In Whitmarsh, R.B., Ross, D.A., et al., Initial Reports of the Deep Sea
Drilling Project, Volume 23: Washington (U.S. Government Printing Office), p. 421.

Roth, P., 1973. Calcareous nannofossils, Leg 17. In Winterer, E.L., Ewing, J.I., et al., Initial Reports of the Deep Sea Drilling Project, Volume 17: Washington (U.S. Government Printing Office), p. 695.

Saito, T. and Van Donk, J., 1974. Oxygen and Carbon isotope measurement of late Cretaceous and early Tertiary foraminifera: Micropaleontology, v. 20, p. 152.

Savin, S. and Douglas, R., 1973. Stable isotope and magnesium geochemistry of Recent planktonic foraminifera from the South Pacific: Geol. Soc. Am. Bull., v. 84, p. 2327.

Savin, S., Douglas, R., and Stehli, F., in press. Tertiary marine paleotemperatures: Geol. Soc. Am. Bull., v. 86.

Schlanger, S.O. and Douglas, R.G., 1974. The pelagic oozechalk-limestone transition and its implication for marine stratigraphy. In Hsu, K.J. and Jenkyns, H.C. (Eds.), Internat. Assoc. Sediment. Petrol., Spec. Pub. 1, p. 117.

Schlanger, S.O., Douglas, R.G., Lancelot, Y., Moore, T.C., and Roth, P., 1973. Fossil preservation and diagenesis of pelagic carbonates from the Magellan Rise, Central North 


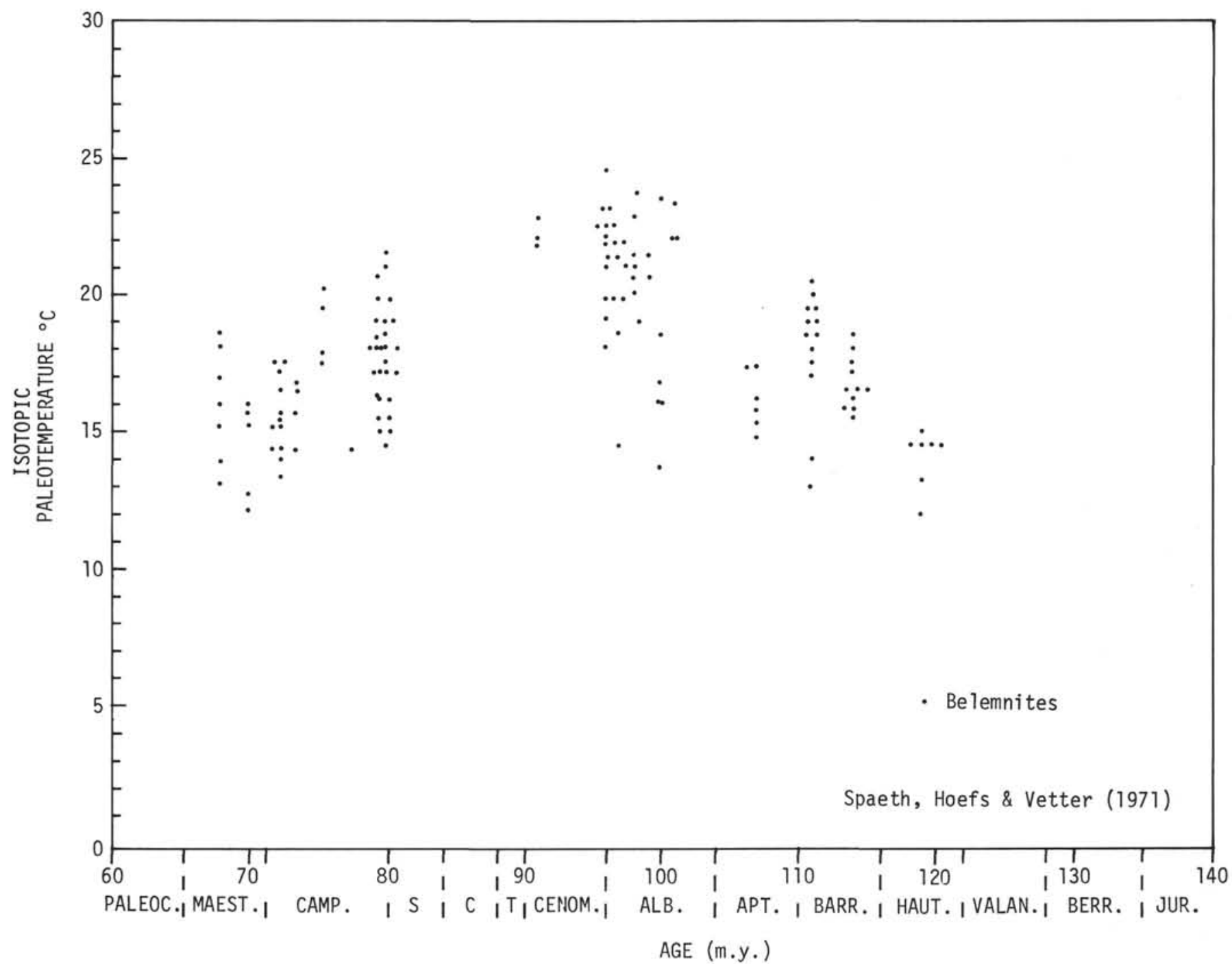

Figure 8. (Continued).

Pacific Ocean. In Winterer, E.L., Ewing, J.I., et al., Initial Reports of the Deep Sea Drilling Project, Volume 17: Washington (U.S. Government Printing Office), p. 467. Scholle, P.A., 1974. Diagenesis of Upper Cretaceous Chalks from England, North Ireland and the North Sea. In Hsu, K.J. and Jenkyns, H.C. (Eds.), Pelagic sediments: on land and under the sea: Internat. Assoc. Sediment. Petrol., Spec. Pub. 1, p. 177.

Spaeth, C., Hoefs, J., and Vetter, V., 1971. Some aspects of isotopic composition of belemnites and related paleotemperatures: Geol. Soc. Am. Bull., v. 82, p. 3139. 